\title{
Phylogenetic Analysis of Snake Using Cytochrome b Gene Sequence
}

\author{
Jadhav Anita S. \\ Department of Zoology, ICLES' Motilal Jhunjhunwala College of Arts, Science and Commerce, Vashi Navi, Mumbai, Maharashtra, \\ India
}

Received: $13^{\text {th }}$ February, 2021

Accepted: 30th March, 2021

Published online: $16^{\text {th }}$ April, 2021

https://doi.org/10.33745/ijzi.2021.v07i01.013

\begin{abstract}
Phylogenetic analysis of two species of snake Eryx colubrinus loveridgei and Ptyas mucosus was investigated using the gene encoding cytochrome $b$. The nucleotide sequences of complete and partial mtDNA cytochrome $b$ were determined in numerous specimens. Sequence divergence between species and genera was evenly distributed in the cytochrome $b$ gene but rather high compared to reports for other fish species. Phylogenetic analyses on complete cytochrome $b$ were used to study the relationships among the considered species. The molecular phylogeny of sample was determined by analyzing cytochrome $b$ gene sequences. On the basis of position of sequence of the given python sample in the phylogenetic tree, the sample showed closest similarity with Eryx colubrinus loveridgei and Ptyas mucosus.
\end{abstract}

Keywords: Eryx colubrinus loveridgei; Ptyas mucosus, DNA sequence, Cytochrome b, Phylogenetic analysis

Citation: Jadhav Anita S.: Phylogenetic analysis of snake using cytochrome b gene sequence. Intern. J. Zool. Invest. 7 (1): 169-175, 2021.

https://doi.org/10.33745/ijzi.2021.v07i01.013

\section{Introduction}

DNA barcoding is a simple technique used to develop a large-scale system of classification that is broadly applicable across a wide variety of taxa. Molecular phylogenetics is the analysis of hereditary molecular differences, mainly in DNA sequences, to gain information on an organism's evolutionary relationships. Molecular phylogeny of snake was determined by analyzing cytochrome b gene. Phylogenies form the cornerstone of our understanding of evolutionary relationships between organisms and provide a historical basis for testing and inferring ecological and evolutionary processes. Rieppel (1988) provided useful historical reviews of progress in understanding snake phylogeny and classification. Hydrophiine or 'true' sea snakes are a diverse radiation of fully marine 
venomous species that belong to the same evolutionary lineage as venomous terrestrial elapids.

Snakes represent a taxonomically underdeveloped group of animals in India with a lack of experts and incomplete taxonomic descriptions being the main deterrents to advances in this area. Veterinary and forensic science laboratories frequently encounter samples lacking any morphological details that make it impossible to identify them as meat, leather, bones, blood stains on clothes. Therefore, there is a need to determine the origin of anonymous biological traces. In addition, species identification represents a key aspect of biodiversity studies (Ardura et al., 2011). The molecular markers and DNA sequencing have been taken as good markers to classify the taxonomy and phylogenetic relationships among species. The application of PCR technique has significantly improved the efficiency of laboratorial diagnostic procedures by allowing the in vitro amplification of a large number of DNA copies using a specific genomic region as template, followed by complementary techniques (Fajardo et al., 2007). Since it only requires a small amount of template DNA, the PCR method has been particularly useful for the identification of species in suboptimal DNA samples like forensic samples and blood stains, also in archaeological remains and museum specimens owing to the highly degraded and fragmented nature of ancient DNA (Pereira et al., 2008).

Both molecular and morphological data sets will ultimately be necessary to develop a comprehensive phylogeny of snakes and each data source can make a unique contribution. On one hand, molecular methods can provide large quantities of phylogenetically informative data. Although data have been plentiful, colubroid molecular phylogenies have been unstable due to their inherent sensitivity to taxon sampling (Kraus and Brown, 1998; Kelly et al., 2003). On the other hand, only few morphological complexes have been analyzed thoroughly within snakes, and the paucity of broadly sampled morphological characters has prevented the compilation of a large morphological data matrix.

The cytochrome $b$ gene has been proved as an efficient tool with high power of discrimination for species identification and characterization in both taxonomy and forensic science (Kuwayama and Ozawa, 2000; Saif et al., 2012) and is also used in studies of molecular evolution (Prusak et al., 2004). The gene length is $1140 \mathrm{bp}$ and has some stable sequences which were used for suggestion of universal primers for typical PCR-based methods (Parson et al., 2000). The application of DNA data to phylogenetic reconstruction has led to the collection of diverse molecular data sets to test taxonomic hypotheses (Flynn, and Wesley-Hunt, 2005).This practice evidently leads to wellsupported, highly resolved trees, compared with individual partitions. However, the acquisition of such data sets is an expensive and time-consuming process. If it is accepted that the best estimate of phylogeny is taken to be the simplest explanation of all the relevant data (i.e. the simultaneous analysis) (Miller et al., 1997), the PBS allows an evaluation of phylogenetic accuracy of all partitions. So, in the present study phylogenetic analysis of snake using cytochrome $b$ gene sequence was investigated.

\section{Materials and Methods}

Collection of samples: 
Shed skin samples of both the snakes were also provided from the Mumbai Zoological Gardens, collected from individual live Sand boa snake and Rat snake encountered in and around residential areas. Ventral scale clip samples and shed skins were taken from captive held specimens of known geographic origin. The sheds were processed and prepared before identification. The sheds were first immersed in clean water and lightly squeezed to soften them and were proceed for DNA extraction.

DNA extraction and quantification:

DNA Extraction from 2-3 scale was carried out using Gen-Elute mammalian genomic DNA miniprep Kit (Sigma-Aldrich). Concentration of DNA was determined using UV-1800 spectrophotometer (Shimadzu Corporation). The DNA was stored at -20 C for further use.

\section{PCR amplification:}

PCR amplification was performed using Biometra thermal cycler. The PCR mixture contained $2.5 \mu \mathrm{l}$ of $10 \mathrm{X}$ buffer, $1 \mu \mathrm{l}$ of each primer (diluted 10 times), $2.5 \mu \mathrm{l}$ of $2.5 \mathrm{mM}$ of each dNTP, 2.5 Units of Taq DNA polymerase and $1 \mu \mathrm{l} \mathrm{Template} \mathrm{DNA.} \mathrm{Primers} \mathrm{used} \mathrm{for} \mathrm{cyt} b$ region amplification were Snk-F: 5' TGAGGACAAATATCATTCTGAG 3' and Snk-R: 5' TAGGCGAATAGGAAGTATCA 3' (Dubey et al., 2010). The PCR amplification cycle consisted of a cycle of $5 \mathrm{~min}$ at $94 \mathrm{C}$; 30 cycles of $45 \mathrm{sec}$ at $94 \mathrm{C}, 45 \mathrm{sec}$ at $45 \mathrm{C}, 1 \mathrm{~min}$ and 30 sec at $72 \mathrm{C}$; and 1 cycle of $5 \mathrm{~min}$ at $72 \mathrm{C}$.

Gel electrophoresis:

Gel electrophoresis was performed using $1.0 \%$ agarose to analyze the size of amplified PCR product. The size obtained was approx. 431bp for cytochrome b region (Fig 4).

DNA sequencing:
The PCR product was purified using AxyPrep PCR Clean up kit (AP-PCR-50). It was further sequenced using Applied Biosystems 3730xl DNA Analyzer USA and chromatogram obtained. The primer used was Snk- F: 5'TGAGGACAAATATCATTCTGAG3' as sequencing primer.

Bioinformatics analysis:

The DNA sequences were analyzed using online nBLAST (nucleotide Basic Local Alignment Search Tool) facility of National Center for Biotechnology Information (NCBI). The BLAST results (Tables 1,2) were used to find out evolutionary relationship of snake. Altogether eleven sequences, including sample were used to generate phylogenetic tree. The tree had been generated in MEGA (Figs. 1, 2).

Figure 1: Phylogenetic tree for Sand boa (2)

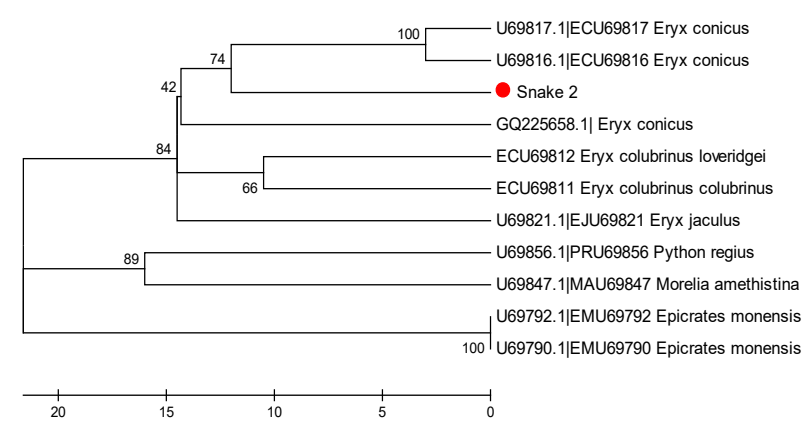

Figure 2: Phylogenetic tree for Rat snake (3)

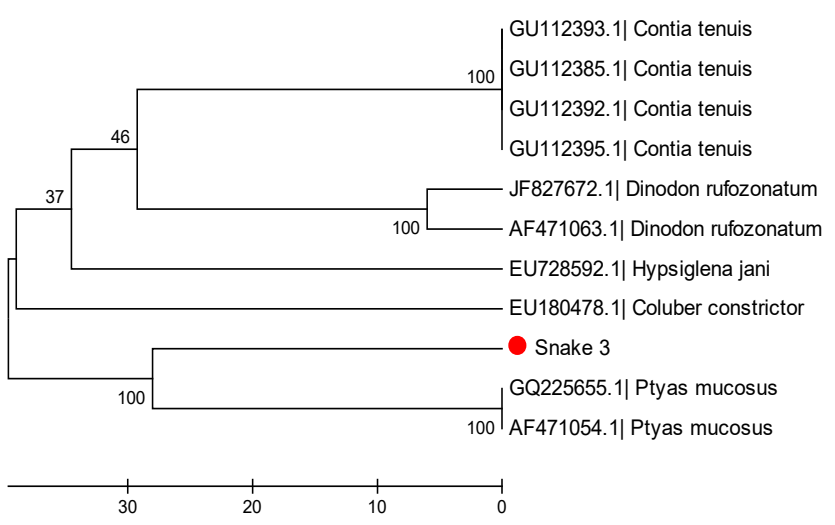




\section{Results and Discussion}

Sample -- Sand boa

Gene Sequences:

> Sand boa Snake

Sequence length: 367

Table 1: Phylogenetic analysis of Sand boa

\begin{tabular}{|c|c|c|c|c|}
\hline $\begin{array}{l}\text { Sr. } \\
\text { no. }\end{array}$ & Description & $\begin{array}{c}\text { Max } \\
\text { score }\end{array}$ & Max ident & Accession \\
\hline 1. & $\begin{array}{l}\text { Eryx colubrinus loveridgei cytochrome b (cytb) gene, } \\
\text { mitochondrial gene encoding mitochondrial protein, } \\
\text { partial cds }\end{array}$ & 398 & $89 \%$ & U69812.1 \\
\hline 2. & $\begin{array}{l}\text { Eryx conicus cytochrome b (Cytb) gene, partial cds; } \\
\text { mitochondrial }\end{array}$ & 375 & $88 \%$ & GQ225658.1 \\
\hline 3. & $\begin{array}{l}\text { Eryx colubrinus colubrinus cytochrome b (cytb) gene, } \\
\text { mitochondrial gene encoding mitochondrial protein, } \\
\text { partial cds }\end{array}$ & 348 & $86 \%$ & U69811.1 \\
\hline 4. & $\begin{array}{l}\text { Eryx conicus cytochrome b (cytb) gene, mitochondrial } \\
\text { gene encoding mitochondrial protein, partial cds }\end{array}$ & 339 & $88 \%$ & U69817.1 \\
\hline 5. & $\begin{array}{l}\text { Eryx jaculus cytochrome b (cytb) gene, mitochondrial } \\
\text { gene encoding mitochondrial protein, partial cds }\end{array}$ & 309 & $87 \%$ & U69821.1 \\
\hline 6. & $\begin{array}{l}\text { Eryx conicus cytochrome b (cytb) gene, mitochondrial } \\
\text { gene encoding mitochondrial protein, partial cds }\end{array}$ & 307 & $88 \%$ & U69816.1 \\
\hline 7. & $\begin{array}{l}\text { Epicrates monensis cytochrome b (cytb) gene, } \\
\text { mitochondrial gene encoding mitochondrial protein, } \\
\text { complete cds }\end{array}$ & 294 & $84 \%$ & U69792.1 \\
\hline 8. & $\begin{array}{l}\text { Epicrates monensis cytochrome b (cytb) gene, } \\
\text { mitochondrial gene encoding mitochondrial protein, } \\
\text { complete cds }\end{array}$ & 294 & $84 \%$ & U69790.1 \\
\hline 9. & $\begin{array}{l}\text { Morelia amethistina cytochrome b (cytb) gene, } \\
\text { mitochondrial gene encoding mitochondrial protein, } \\
\text { partial cds }\end{array}$ & 292 & $85 \%$ & U69847.1 \\
\hline 10. & $\begin{array}{l}\text { Python regius cytochrome b (cytb) gene, mitochondrial } \\
\text { gene encoding mitochondrial protein, partial cds }\end{array}$ & 285 & $84 \%$ & U69856.1 \\
\hline
\end{tabular}


Sample --Rat snake

Gene Sequences:

>Snake Rat snake

AGGGGGAGGGGGGAGGAGGGGTGCTTCAATTTGGGGATACCAACTGCTAACCCGGTTGGTTGGGCC

TACGGTTTATCCTTCCGGGAGTATCATGTCAATGTCCTCAATCCACATCATACTGCTTCACACAGA

AGATCAAGCAACCCGCTAGGAACAAATTCAGACATGGACAAAATTCCATTTCACCCATACCACTCC

CACAAAGATATCCTAATACGAACGGTATTAATTACCATAATATTTACTATTATAGCATTCACCCCA

AACATAGGTGATGAGCCAGAAAATGTCTCAAAAGCTAATCCAATAGTCGCACCACAACACATTAA

ACCAGAAGGATACTTCCTAGTCGCCTAAGA

Sequence length: 359

Table 2: Phylogenetic analysis of Rat snake

\begin{tabular}{|l|l|c|c|c|}
\hline $\begin{array}{c}\text { Sr } \\
\text { no. }\end{array}$ & \multicolumn{1}{|c|}{ Description } & $\begin{array}{c}\text { Max } \\
\text { score }\end{array}$ & $\begin{array}{c}\text { Max } \\
\text { identity }\end{array}$ & $\begin{array}{c}\text { Accession } \\
\text { no. }\end{array}$ \\
\hline 1. & $\begin{array}{l}\text { Ptyas mucosus CAS 208434 cytochrome b (cytb) gene, complete cds; } \\
\text { mitochondrial }\end{array}$ & 392 & $89 \%$ & AF471054.1 \\
\hline 2. & Ptyas mucosus cytochrome b (Cytb) gene, partial cds; mitochondrial & 381 & $88 \%$ & GQ225655.1 \\
\hline 3. & $\begin{array}{l}\text { Dinodon rufozonatum LSUMZ 44977 cytochrome b (cytb) gene, } \\
\text { complete cds; mitochondrial }\end{array}$ & 243 & $83 \%$ & AF471063.1 \\
\hline 4. & $\begin{array}{l}\text { Dinodon rufozonatumisolate china cytochrome b (cytb) gene, partial } \\
\text { cds; mitochondrial }\end{array}$ & 220 & $82 \%$ & JF827672.1 \\
\hline 5. & $\begin{array}{l}\text { Coluber constrictor voucher KJI 3 cytochrome b gene, partial cds; } \\
\text { mitochondrial }\end{array}$ & 198 & $80 \%$ & EU180478.1 \\
\hline 6. & $\begin{array}{l}\text { Hypsiglena jani texana voucher CAS 228960 mitochondrion, } \\
\text { complete genome }\end{array}$ & 193 & $80 \%$ & EU728592.1 \\
\hline 7. & $\begin{array}{l}\text { Contia tenuis voucher MVZ 232671 cytochrome b (cytb) gene, } \\
\text { complete cds; mitochondrial }\end{array}$ & 189 & $80 \%$ & GU112395.1 \\
\hline 8. & $\begin{array}{l}\text { Contia tenuis voucher MVZ 208160 cytochrome b (cytb) gene, } \\
\text { complete cds; mitochondrial }\end{array}$ & 189 & $80 \%$ & GU112393.1 \\
\hline 9. & $\begin{array}{l}\text { Contia tenuis voucher MVZ 208158 cytochrome b (cytb) gene, } \\
\text { complete cds; mitochondrial }\end{array}$ & 189 & $80 \%$ & GU112392.1 \\
\hline 10. & $\begin{array}{l}\text { Contia tenuis voucher CAS 205652 cytochrome b (cytb) gene, } \\
\text { complete cds; mitochondrial }\end{array}$ & 189 & $80 \%$ & GU112385.1 \\
\hline
\end{tabular}


Two molecular studies [partial16S and cytochrome b mtDNA sequences; amino acid sequences of the venom proteins PLA2 and NXS] (Keogh, 1998) have explored the phylogenetic relationships within the snake family Elapidae, a major group of venomous snakes containing nearly 300 species in approximately 60 genera (Golay et al., 1993); herein we use Elapidae in the broad sense to include both terrestrial and marine species, whereas Golay et al.(1993) place the marine species in a separate family Hydrophiidae). The two studies agree that the marine and Australo-Melanesian species are collectively mono-phyletic.

Initial phylogenetic analyses using maximum likelihood joined acrodonts with snakes instead of with iguanids. The affinities of snakes and acrodonts were thus analyzed separately in subsequent analyses. Furthermore, the most fast-evolving taxa were removed by creating a distance matrix based on them tREV+I+8 model and compared distances between each squamate taxon and the turtles. Any squamate taxon that had a distance of 1.0 or more was removed. The taxon sampling may have been compromised but it was only compromised within, not across, lineages. In addition, fast-evolving taxa only mask the true phylogenetic signal of the data and, as was evident, increase the likelihood of LBA (Baurain et al., 2007)

These results are congruent with previous phylogenetic studies with respect to the affinities of lizard lineages.These results support a mitogenomic study that also place snakes with the "Laterata" (Kumazawa, 2007). These results are in contrast to nuclear gene studies and phylogenetic analysis of snake like Eryx colubrinus loveridgei and Ptyas mucosus.

\section{References}

Ardura A, Planes S and Garcia Vazquez E. (2011) Beyond biodiversity: fish metagenomes. PLoS One 6: e22592.

Dubey B, Meganathan PR and Haque I. (2010) Molecular identification of three Indian snake species using simple PCR-RFLP method. J Forensic Sci. 55:1065-1067.

Fajardo V, González I, López-Calleja I, Martín I, Rojas M and Pavón MA. (2007) Analysis of mitochondrial DNA for authentication of meats from chamois (Rupicapra rupicapra), pyrenean ibex (Capra pyrenaica), and mouflon (Ovis ammon) by polymerase chain reaction restriction fragment length polymorphism. J AOAC Int. 90:179-186.

Felsenstein J. (1985) Confidence limits on phylogenies: An approach using the bootstrap. Evolution 39: 783-791.

Flynn JJ and Wesley-Hunt GD. (2005) Carnivora. In: The Rise of Placental Mammals: Origins and Relationships of the Major Extant Clades, (eds.) Archibald D and Rose K. Baltimore, MD: Johns Hopkins University Press, pp.175-98.

Golay P, Smith HM, Broadley DG, Dixon JR, McCarthy C, Rage JC, Schatti B and Toriba M. (1993) Endoglyphs and other major venomous snakes of the world: A Checklist, Azemiops, S. A., Switzerland.

Kelly CMR, Barker NP and Villet MH. (2003) Phylogenetics of advanced snakes (Caenophidia) based on four mitochondrial genes. Syst Biol. 52: 439-459.

Keogh JS, Shine R and Donnellan S. (1998) Phylogenetic relationships of terrestrial Australo-Papuan elapid snakes (Subfamily: Hydrophiinae) based on cytochrome $b$ and 16S rRNA sequences. Mol Phylogenet Evol. 10: 67-81.

Kraus F and Brown WM. (1998) Phylogenetic relationships of colubroid snakes based on mitochondrial DNA sequences. Zool J Linn Soc. 122: 455-487.

Kuwayama R and Ozawa T. (2000) Phylogenetic relationships among European red deer, wapiti, and sika deer inferred from mitochondrial DNA sequences. Mol Phylogenet Evol. 15:115-123.

Miller JS, Brower AVZ and DeSalle R. (1997) Phylogeny of the neotropical moth tribe Josiini (Notodontidae: Diop-tinae): comparing and combining evidence from DNA sequences and morphology. Biol J Linn Soc. 60:297-316.

National Centre for Biotechnology Information (NCBI) website. 
Parson W, Pegoraro K, Niederstatter H, Foger M and Steinlechner M. (2000) Species identification by means of the cytochrome $b$ gene. Int J Legal Med. 114: 23-28.

Pereira FC and Amorim A. (2008) Identification of species with DNA-based technology: current progress and challenges. Recent Pat DNA Gene Seq. 2:187-200.

Prusak B, Grzybowski G and Zięba G. (2004) Taxonomic position of Bison bison (Linnaeus, 1758) and Bison bonasus (Linnaeus, 1758) based on analysis of cytb gene. Anim Sci Pap Rep. 22:27-35.

Rieppel O. (1988). A review of the origin of snakes. Evol Biol. 22: 37-130.

Saif R, Babar ME, Awan AR, Nadeem A, Hashmi AS and Hussain T. (2012) DNA fingerprinting of Pakistani buffalo breeds (Nili-Ravi, Kundi) using microsatellite and cytochrome b gene markers. Mol Biol Rep. 39: 851-856.
Saitou N and Nei M. (1987) The neighbor-joining method: A new method for reconstructing phylogenetic trees. Mol Biol Evol. 4: 406-425.

Tamura K, Nei M and Kumar S. (2004) Prospects for inferring very large phylogenies by using the neighbor-joining method. Proc Nat Acad Sci. (USA) 101:11030-11035.

Tamura K, Peterson D, Peterson N, Stecher G, Nei M and Kumar S. (2011) MEGA5: Molecular Evolutionary genetics analysis using maximum likelihood, evolutionary distance, and maximum parsimony methods. Mol Biol Evol. 28:2731-2739. 